\title{
The Effect of Nocodazole on Cell Cycle Events in the Plasmodial Slime Mould Physarum polycephalum
}

\author{
By A. S. MCCLORY† AND J. G. COOTE* \\ Microbiology Department, University of Glasgow, Garscube Estate, Bearsden, \\ Glasgow G61 1QH, UK
}

(Received 7 October 1986; revised 25 November 1986)

\begin{abstract}
The action of nocodazole on nuclear morphology, DNA replication and thymidine (TdR) kinase activity has been examined in growing and starving plasmodia of the CL strain of Physarum polycephalum. In the growing plasmodium, nocodazole treatment more than $2 \mathrm{~h}$ before mitosis began prevented both mitosis and DNA replication from occurring at the normal time and also prevented the increase in TdR kinase specific activity normally associated with the onset of mitosis. Nocodazole treatment less than $2 \mathrm{~h}$ before mitosis began allowed the process to begin at the normal time, but it was not completed. A normal increase in TdR kinase specific activity accompanied the abortive mitosis, but only limited DNA replication was detected. A similar effect of nocodazole on the occurrence of DNA synthesis in starving plasmodia was found. Nocodazole treatment of a starved plasmodium re-fed with growth medium indicated that the plasmodium was in the G2 phase of the cell cycle when it became competent to sporulate.
\end{abstract}

\section{INTRODUCTION}

The plasmodium of the myxomycete Physarum polycephalum exhibits natural synchrony of cell cycle events whereby as many as $10^{8}$ nuclei can undergo mitosis and DNA replication in a synchronous manner (Guttes \& Guttes, 1964; Braun et al., 1965). DNA is replicated during an S phase which lasts 2 to $3 \mathrm{~h}$ and starts immediately after the mitotic divisions of the nuclei (Braun et al., 1965). There is a negligible Gl period in the growing plasmodium (Kubbies \& Pierron, 1983). The experiments of Guttes \& Guttes (1968) indicated that DNA replication was triggered by passage of the nuclei through mitosis. However, only the occurrence of the early events in the mitotic process seemed necessary for the onset of DNA replication because if the terminal stages (anaphase and telophase) were prevented, by heat shock (Brewer \& Rusch, 1968; Wright \& Tollon, 1978; Wolf et al., 1979) or by the action of the anti-tumour drug cysplatin (Wright et al., 1984), DNA replication still occurred.

The anti-tubulin drugs griseofulvin and nocodazole prevent the polymerization of tubulin protein into microtubules and so block nuclear division. Prolonged treatment of plasmodia with either of these drugs gave rise to giant polyploid nuclei, indicating that DNA replication had continued in the absence of nuclear division (Gull \& Trinci, 1974; Wright et al., 1976). A later study showed that griseofulvin caused a delay in mitosis of up to $6 \mathrm{~h}$ if applied in mid-cycle some 5 to $6 \mathrm{~h}$ before metaphase (Herbert et al., 1980). Mitotic delay was progressively reduced as the drug was added closer to metaphase until at $1.5 \mathrm{~h}$ or less no mitotic delay was observed. Instead, the nuclei exhibited an abnormal morphology whereby the chromosomes assumed a ring-like configuration instead of condensing in a normal metaphase plate. As DNA synthesis was not specifically measured in these experiments, we examined the effect of nocodazole on DNA

† Present address: Veterinary Pathology Department, Veterinary School, Garscube Estate, Bearsden, Glasgow G61 1QH, UK.

Abbreviation: $\mathrm{TdR}$, thymidine. 
replication, nuclear morphology and the cell cycle dependent increase in thymidine (TdR) kinase (EC 2.7.1.21) specific activity on exposure of plasmodia to nocodazole at intervals approaching mitosis. Disturbance of the cell cycle by nocodazole was also used to indicate that a plasmodium is in the G2 phase of the cell cycle when it becomes competent to sporulate.

\section{METHODS}

Organism and cultivation. The apogamic, haploid Colonia Leicester (CL) strain of P. polycephalum was used (Cooke \& Dee, 1975). It was grown at $24^{\circ} \mathrm{C}$ in semi-defined growth medium (GM) (Chapman \& Coote, 1982) as a shaken suspension of microplasmodia. For surface culture of a plasmodium, a $10 \mathrm{ml}$ sample of microplasmodia was centrifuged $(500 \mathrm{~g}, 2 \mathrm{~min})$, and the pelleted microplasmodia were suspended in $0 \cdot 1 \mathrm{ml}$ sterile distilled water and then spread in a circle on to a filter paper (Whatman no. 50) supported on a wire grid in a $15 \mathrm{~cm}$ glass Petri dish. GM was introduced beneath the filter to soak the paper and the Petri dish incubated in the dark at $24^{\circ} \mathrm{C}$. To obtain a starved plasmodium, a surface plasmodium was prepared and grown for $42 \mathrm{~h}$ with GM. After this time, the filter was removed, drained and transferred to a fresh Petri dish. Sporulation medium (SM) (Chapman \& Coote, 1982) was then introduced beneath the filter paper and the Petri dish incubated in the dark at $24^{\circ} \mathrm{C}$.

DNA synthesis in plasmodia. Small pieces (approximately $1 \mathrm{~cm}$ square) were cut at intervals from a filter paper supporting either a growing or a starving plasmodium. Each piece was transferred to a wire grid in a Petri dish containing either GM or SM with added $\left[\right.$ methyl $\left.{ }^{-3} \mathrm{H}\right] \mathrm{TdR}\left(7.4 \mathrm{kBq} \mathrm{ml} l^{-1} ; 1.74 \mathrm{Tbq} \mathrm{mmol}^{-1}\right.$; from Amersham) and incubated at $24{ }^{\circ} \mathrm{C}$ for $30 \mathrm{~min}$. It was then put into $20 \mathrm{ml}$ cold TCA/acetone (equal volumes of $8 \%, w / v, T C A$ and acetone) for $10 \mathrm{~min}$ which removed all the pigment from the section of plasmodium. After centrifugation $(1000 \mathrm{~g}$, $5 \mathrm{~min}$ ) the $A_{400}$ of the supernatant was noted and used to estimate the amount of material collected in order to standardize the radioactivity incorporated into each sample. The precipitate was washed twice in $0.25 \mathrm{M}$ perchloric acid containing $\mathrm{TdR}\left(100 \mu \mathrm{g} \mathrm{ml}^{-1}\right)$ and finally solubilized in $2 \mathrm{ml} 0.4 \mathrm{M}-\mathrm{NaOH}$. The radioactivity in $1 \mathrm{ml}$ of the sample was counted in a Packard Tri-carb $300 \mathrm{C}$ scintillation counter.

$T d R$ kinase assay. A modification of the procedure of Wright \& Tollon (1979a) was used. Small pieces were cut at intervals from a filter paper and the portion of plasmodium was suspended in $0.25 \mathrm{ml}$ ice-cold $50 \mathrm{mM}$-Tris/HCl (pH 7.5), $25 \%$ (v/v) glycerol, $5 \mathrm{~mm}$-2-mercaptoethanol, quickly homogenized with 10 strokes in a Potter-Elvehjem glass homogenizer, frozen in dry ice/acetone and stored at $-70^{\circ} \mathrm{C}$. After thawing on ice the suspension was centrifuged $\left(23000 \mathrm{~g}, 15 \mathrm{~min}\right.$ at $\left.4^{\circ} \mathrm{C}\right)$ and $10 \mu \mathrm{l}$ of supernatant added to an incubation mixture which contained in a total volume of $40 \mu \mathrm{l}: 75 \mathrm{~mm}-\mathrm{Tris} / \mathrm{HCl}(\mathrm{pH} 7.5), 7 \mathrm{~mm}-\mathrm{ATP}, 3.5 \mathrm{~mm}-\mathrm{MgCl}_{2}, 1 \mathrm{~mm}-\mathrm{EDTA}, 1.5 \mathrm{~mm}-2-$ mercaptoethanol, $500 \mu \mathrm{g}$ bovine serum albumin $\mathrm{ml}^{-1}$ (Sigma), $10 \mu \mathrm{M}-\mathrm{TdR}$ and $18.5 \mathrm{kBq}\left[\right.$ methyl- $\left.{ }^{-3} \mathrm{H}\right] \mathrm{TdR}$ (1.74 TBq mmol-1; Amersham). After $30 \mathrm{~min}$ incubation at $24{ }^{\circ} \mathrm{C}$ the samples were placed on ice for $30 \mathrm{~min}$. They were then diluted with $5 \mathrm{ml}$ distilled water containing $\mathrm{TdR}\left(100 \mu \mathrm{g} \mathrm{ml}^{-1}\right)$, filtered slowly through Whatman DE81 filters to bind phosphorylated $T d R$ and then washed with $5 \mathrm{ml}$ distilled water $+\mathrm{TdR}$ and $10 \mathrm{ml}$ distilled water. The filters were dried and the radioactivity was counted. Units of activity are expressed as pmol TdR phosphorylated $\mathrm{min}^{-1}$ and specific activity is expressed as units (mg protein) ${ }^{-1}$. Protein was estimated by the Lowry method using bovine serum albumin (Sigma) as standard.

Microscopy. The occurrence of mitosis was noted using a phase contrast light microscope (Vickers Instruments, magnification $\times 1000$ ) by observation of ethanol-fixed smears (Guttes \& Guttes, 1964). For electron microscope observations, samples were prepared as described by Herbert et al. (1980). Samples were fixed for $1 \mathrm{~h}$ in $2 \cdot 5 \%(\mathrm{v} / \mathrm{v})$ glutaraldehyde in $100 \mathrm{~mm}$-sodium cacodylate $(\mathrm{pH} 7 \cdot 2)$ containing $8 \%(\mathrm{w} / \mathrm{v})$ tannic acid and $3 \mathrm{~mm}-\mathrm{CaCl}_{2} . \mathrm{Samples}$ were post-fixed in $2 \%(\mathrm{w} / \mathrm{v})$ osmium tetroxide and $0.5 \%(\mathrm{w} / \mathrm{v})$ uranyl acetate and embedded in Epon. Thin sections were examined in a Philips EB300 electron microscope operated at $60 \mathrm{kV}$.

Chemicals. All chemicals used were analytical grade. Nocodazole (Sigma) was prepared as a stock solution $\left(5 \mathrm{mg} \mathrm{ml}^{-1}\right)$ in dimethyl sulphoxide (DMSO) and stored at $-20^{\circ} \mathrm{C}$. It was diluted in media to the required final concentration and the equivalent amount of solvent added to control media had no effect on the organism.

\section{RESULTS}

\section{Nocodazole treatment of growing plasmodia}

A plasmodium, which had been growing for $20 \mathrm{~h}$ on filter paper, was cut into six portions; one portion was treated with DMSO only, as a control, and the remaining five portions were shifted, at hourly intervals, to GM containing nocodazole. DNA synthesis was measured in each portion at hourly intervals and when nuclei in the control portion were seen to be entering prophase, samples were taken from all six portions for electron microscopy. Further samples for electron microscopy were taken when control nuclei had completed mitosis and were beginning nucleolar reconstruction (Guttes \& Guttes, 1964). 

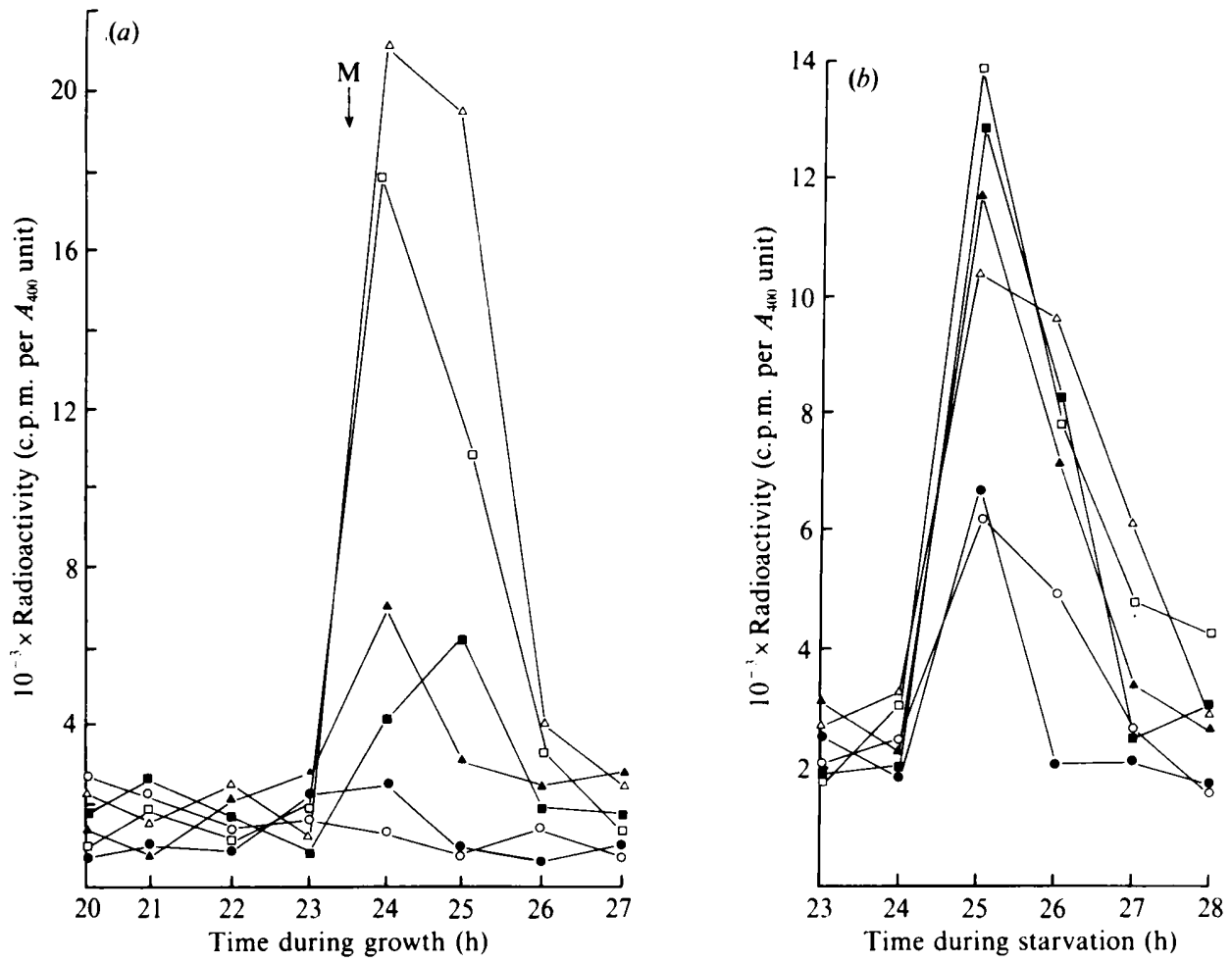

Fig. 1. Representative experiments showing the effect on DNA synthesis of exposure of portions of a plasmodium to nocodazole.. (a) A plasmodium was grown for $20 \mathrm{~h}$ with GM and then divided into six parts, five of which were transferred to GM + nocodazole $(50 \mu \mathrm{M})$ at $20 \mathrm{~h}(0), 21 \mathrm{~h}(\mathrm{O}), 22 \mathrm{~h}(\square), 23 \mathrm{~h}$ $(\triangle), 24 \mathrm{~h}(\square)$ and one transferred to GM + DMSO as a control $(\triangle)$. DNA synthesis was measured in GM with radiolabelled TdR (see Methods) in small pieces cut from each plasmodial portion at hourly intervals. The beginning of mitosis $(M)$ was noted in the control portion by examination of smears in the light microscope. (b) A plasmodium was starved for $23 \mathrm{~h}$ with SM and then treated as in (a) except that portions were transferred to SM + nocodazole at $23 \mathrm{~h}(\bigcirc), 24 \mathrm{~h}(\mathrm{O}), 25 \mathrm{~h}(\square), 26 \mathrm{~h}(\Delta), 27 \mathrm{~h}(\square)$ and one transferred to SM + DMSO as a control $(\triangle)$. DNA synthesis was measured in SM + radiolabelled $\mathbf{T d R}$.

In a representative experiment (Fig. $1 a$ ), mitosis began $15 \mathrm{~min}$ after the $23 \mathrm{~h}$ time point and DNA replication was at a peak in the control sample assayed at $24 \mathrm{~h}$. Exposure to nocodazole at 20 or $21 \mathrm{~h}$ prevented DNA replication from occurring at the normal time. Electron microscope examination of nuclei in these samples revealed only interphase nuclei with a prominent central nucleolus (Guttes \& Guttes, 1964) at the time when control nuclei were undergoing mitosis. Mitosis and DNA replication were thus delayed by exposure to the drug $2 \mathrm{~h} 15 \mathrm{~min}$ and $3 \mathrm{~h}$ 15 min prior to mitosis; a similar mitotic delay was induced by griseofulvin (Herbert et al., 1980). Exposure to nocodazole at 22 and $23 \mathrm{~h}$, i.e. $1 \mathrm{~h} 15 \mathrm{~min}$ and $15 \mathrm{~min}$ respectively before prophase, allowed limited DNA replication to occur at the normal time (Fig. 1 $a$ ). Examination of the nuclei from both portions revealed that all the nuclei underwent the first stage of mitosis normally, as excentric nucleoli, characteristic of prophase (Guttes \& Guttes, 1964), were present (Fig. $2 a$ ) at the same time as in the control portion. However, in later samples, taken after mitosis was completed in the control, there was clear evidence that mitosis had been blocked. In the sample exposed to nocodazole only $15 \mathrm{~min}$ before prophase, nuclei still showed an excentric nucleolus and there was evidence in most nuclei of material surrounding the nucleolus which may have been condensed chromatin (Fig. $2 b$ ). Occasionally, larger, apparently polynucleolate nuclei also containing evidence of condensed chromatin were seen (Fig. $2 c$ ). For the nuclei exposed to nocodazole $1 \mathrm{~h} 15 \mathrm{~min}$ prior to the onset of mitosis, where DNA replication was also 

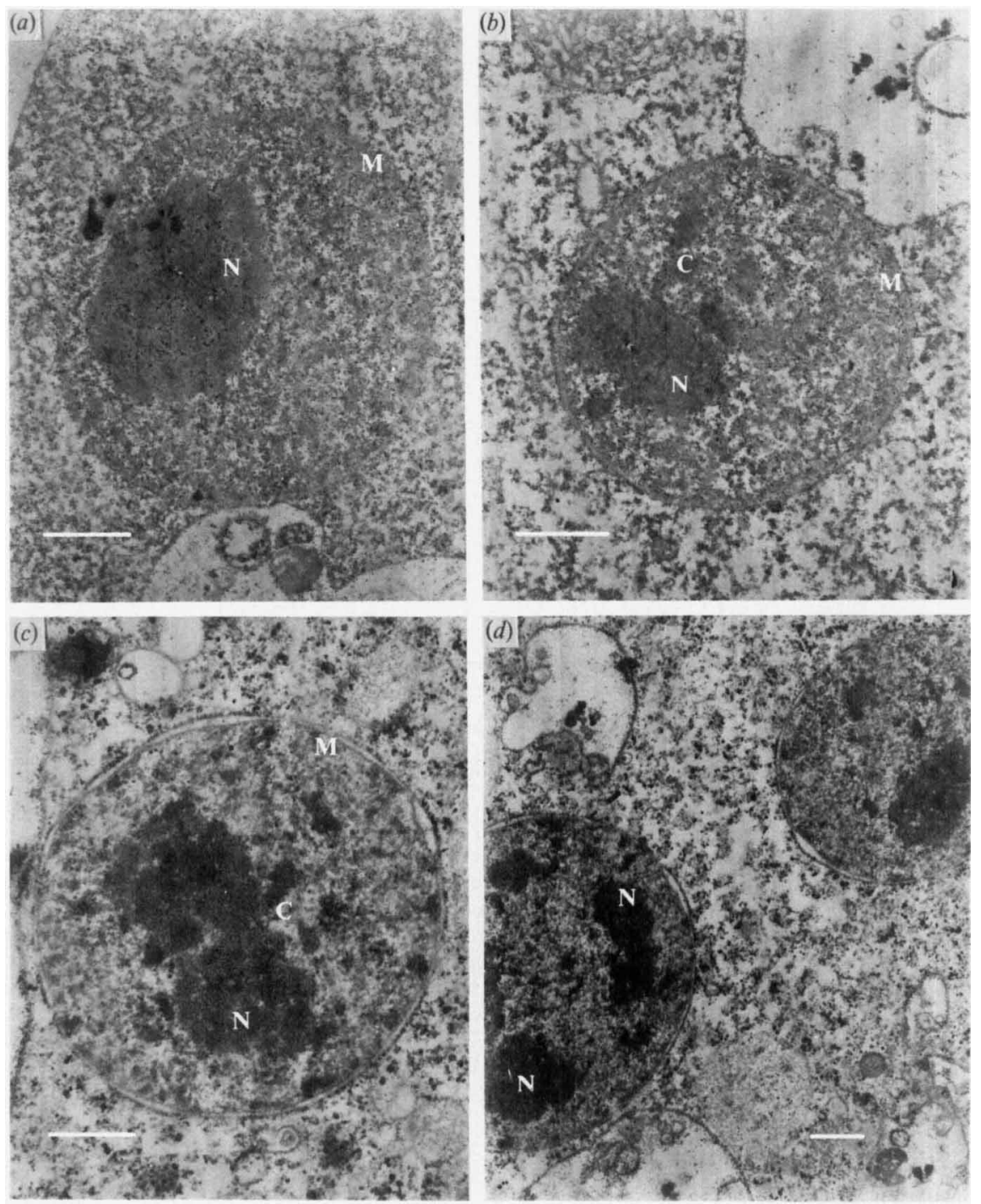

Fig. 2. Electron micrographs of nuclei after treatment of plasmodia with nocodazole. (a) Excentric nucleolus during prophase from a plasmodium treated with nocodazole 75 min before mitosis. $(b)-(d)$ Nuclei from plasmodia treated with nocodazole $15 \mathrm{~min}(b, c)$ or $75 \mathrm{~min}(d)$ before mitosis and sampled for microscopy when mitosis was complete in the control. $\mathrm{N}$, nucleolus; $\mathrm{M}$, nuclear membrane; $\mathrm{C}$, condensed chromatin; bars, $1 \mu \mathrm{m}$.

detected, again normal nuclear division had not occurred. Here the majority of nuclei were large and polynucleolate with abundant condensed chromatin associated with the nucleolus (Fig. $2 d$ ). In neither case were nuclei found which had completed mitosis normally, indicating that the limited DNA replication found in the plasmodial portions exposed to nocodazole at 22 and $23 \mathrm{~h}$ was not due to a low number of nuclei escaping the action of the drug and undergoing mitosis and DNA replication normally. Exposure to nocodazole at $24 \mathrm{~h}$, when DNA replication was at a peak in the control, had little effect on DNA synthesis (Fig. 1a).

\section{$T d R$ kinase activity after nocodazole treatment}

The specific activity of TdR kinase begins to increase about $1 \mathrm{~h}$ before prophase, peaks during $S$ phase and thereafter declines to a minimum during the $G 2$ phase of the cell cycle 

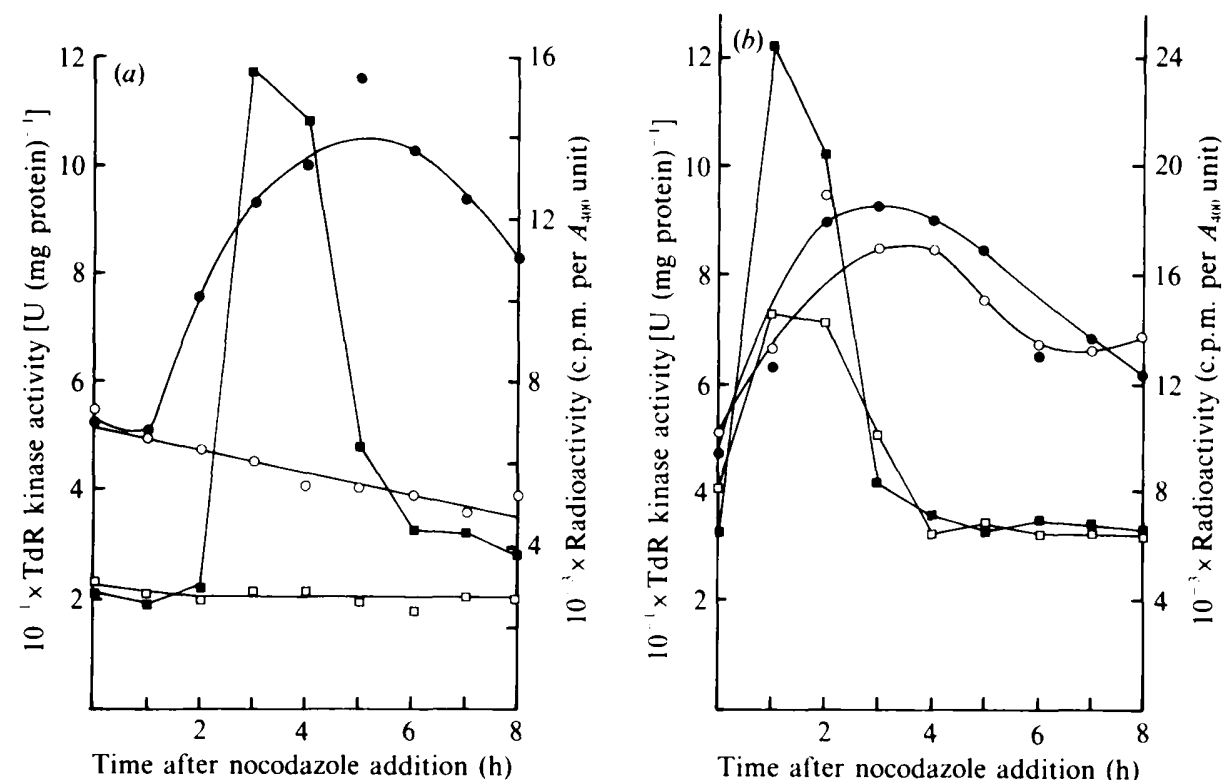

Fig. 3. Representative experiments showing TdR kinase activity and DNA replication after treatment of growing plasmodia with nocodazole. In separate experiments, plasmodia were grown for $22 \mathrm{~h}(a)$ or $23 \mathrm{~h}(b)$ with GM and then divided into two parts; one part was transferred to $\mathrm{GM}+$ nocodazole $(50 \mu \mathrm{M})$ and the other to GM + DMSO as control. DNA synthesis $(\square, \square)$ and TdR kinase activity $(O$, O) were measured in small portions of the plasmodia removed at hourly intervals. $\square, O$, Nocodazole treated; $\mathbf{D}$, control.

(Sachsenmaier et al., 1967). It is therefore a convenient marker event for the cell cycle and is closely associated with the onset of mitosis (Sachsenmaier et al., 1970; Wright \& Tollon, 1979b). We assayed TdR kinase activity and DNA replication after exposure of growing plasmodia to nocodazole. Treatment with the drug between 2 and $3 \mathrm{~h}$ prior to the onset of mitosis prevented the occurrence of the round of DNA replication which was detected in the control, as expected (Fig. $3 a$ ). In the control, TdR kinase specific activity began to increase between 1 and $2 \mathrm{~h}$ prior to the peak of DNA synthesis. Activity peaked during the latter part of the $\mathrm{S}$ phase and then declined. In the plasmodial portion where nocodazole treatment had prevented DNA synthesis, the rise in $T d R$ kinase specific activity was also not detected. This experiment, whereby nocodazole was added to a plasmodium at a time greater than $2 \mathrm{~h}$ prior to the onset of mitosis such that DNA replication did not occur, was repeated three times and although the peak of DNA synthesis in control plasmodia varied between 23 and $25 \mathrm{~h}$ in each case, no increase in TdR kinase activity was detected. Fig. $3(b)$ shows the result obtained when a plasmodium was exposed to nocodazole sufficiently close to mitosis to allow limited DNA replication to occur. Exposure to the drug $1 \mathrm{~h}$ before the peak of DNA synthesis in the control (Fig. $3 b$ ) allowed reduced DNA replication and an increase in TdR kinase activity which, in two experiments, closely followed the increase in the control and in both cases appeared to be only slightly decreased at its peak from that of the control.

\section{Nocodazole treatment of starving plasmodia}

Experiments similar to that described in Fig. 1 (a) for a growing plasmodium were also done on plasmodia treated with starvation medium. Previous work (Chapman \& Coote, 1982) had indicated that a $72 \mathrm{~h}$ period of starvation was necessary before a plasmodium became competent to sporulate in response to illumination. Three periods of DNA synthesis were detected during the initial $24 \mathrm{~h}$ of starvation. A representative experiment (Fig. $1 b$ ) shows that a round of DNA replication in the control portion of the plasmodium began between 24 and $25 \mathrm{~h}$ after the onset 


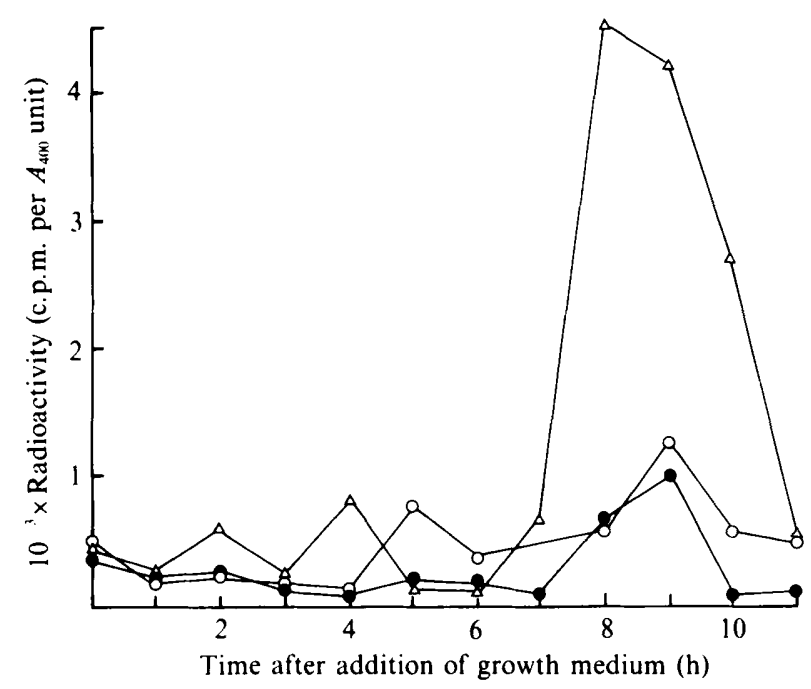

Fig. 4. A representative experiment showing DNA synthesis in a starved plasmodium after refeeding with growth medium. A plasmodium was starved for $72 \mathrm{~h}$ with $\mathrm{SM}$ and then divided into three parts. These were transferred to $\mathrm{GM}$ alone $(\triangle), \mathrm{GM}+$ nocodazole $(50 \mu \mathrm{M})(\mathrm{O})$ or $\mathrm{GM}+$ hydroxyurea $(6 \mathrm{mM})(\mathrm{O})$. DNA synthesis was measured in GM with radiolabelled TdR in small pieces cut from each portion at hourly intervals.

of starvation. Exposure of portions of the plasmodium to nocodazole at 23 and $24 \mathrm{~h}$ allowed DNA replication to occur at the normal time, but as was found with the growing plasmodium, this was again at a reduced level compared with the control or in portions of the plasmodium exposed to the drug at 25,26 or $27 \mathrm{~h}$, when DNA replication was already in progress. In several experiments similar to those in Fig. 1, three with growing plasmodia and four with starving plasmodia, the peak of DNA synthesis in control plasmodia varied between 24 and $29 \mathrm{~h}$, but in all cases exposure to nocodazole $2 \mathrm{~h}$ or less prior to the peak of DNA synthesis in the control allowed limited DNA replication to occur but this was accompanied by incomplete nuclear division. Exposure to nocodazole for periods longer than $2 \mathrm{~h}$ in all cases prevented both DNA replication and mitosis from occurring at the normal time.

The fact that nocodazole treatment of plasmodia $2 \mathrm{~h}$ or more prior to a round of DNA replication prevented mitosis and the following DNA replication from occurring afforded a means of confirming the stage in the cell cycle at which a plasmodium became competent to sporulate after the required $72 \mathrm{~h}$ of starvation. Although three rounds of DNA replication were detected during the initial $24 \mathrm{~h}$ of starvation (Chapman \& Coote, 1982) there was some evidence that a further mitosis, unaccompanied by DNA replication, may have occurred after this time leaving the plasmodium in the G1 phase of the cell cycle when it became competent to respond to light and sporulate after $72 \mathrm{~h}$. It is difficult to unequivocally identify mitosis in starving plasmodia, especially at later stages, by microscopic examination of ethanol-fixed smears because of the degeneration of many nuclei during starvation (Guttes et al., 1961). A starved plasmodium, competent to sporulate at $72 \mathrm{~h}$, will, however, resume growth if transferred to fresh GM as commitment to the sporulation process only occurs $4 \mathrm{~h}$ post-illumination (Sauer et al., 1969; Chapman \& Coote, 1982). If a starved plasmodium was in the Gl phase of the cell cycle then, on resumption of growth, DNA replication would occur first, but if the plasmodium was in the G2 phase, cell cycle events would resume with mitosis. In the former case, the presence of nocodazole would not affect the round of DNA replication whereas in the latter case, mitosis and the ensuing DNA replication would not occur if the plasmodium was exposed to the drug for longer than $2 \mathrm{~h}$ (Fig. 1 a). A plasmodium which had been incubated with SM for $72 \mathrm{~h}$ was divided into three parts, one part placed on GM with nocodazole, another on GM with hydroxyurea (Sigma) and the other on GM alone (Fig. 4). In the control portion DNA synthesis 
began $7 \mathrm{~h}$ after re-feeding with GM, but was insignificant in the portions exposed to the drugs. Thus, hydroxyurea, an inhibitor of DNA synthesis, prevented DNA replication as expected. The fact that nocodazole also prevented DNA synthesis indicated that the original starved plasmodium was in the G2 phase of the cell cycle. It would have had to have restarted its cell cycle with mitosis, but exposure to nocodazole for $7 \mathrm{~h}$ would have prevented this and the ensuing DNA replication from occurring.

\section{DISCUSSION}

Exposure of growing or starving plasmodia to nocodazole $2 \mathrm{~h}$ or more before the onset of mitosis prevented that mitosis and the following DNA replication from occurring and also prevented the increase in $\mathrm{TdR}$ kinase specific activity which normally accompanies the onset of mitosis. Nocodazole treatment less than $2 \mathrm{~h}$ prior to the onset of mitosis allowed nuclear division to begin at the normal time, but this was not completed. DNA replication and the increase in TdR kinase specific activity occurred at the normal time, but whereas TdR kinase appeared to increase in a similar way to that of the control, DNA replication was markedly reduced. It is not clear what this limited DNA replication represents; either normal replication occurs in a fraction of the nuclei and none in others or reduced replication occurs in all nuclei. The nuclei exposed to nocodazole underwent the first stage of mitosis, migration of the nucleolus to the periphery of the nuclear membrane. Apart from evidence of condensed chromatin, progress beyond this point did not occur, at least until the time that the nuclei were sampled, which was when mitosis was completed in controls. We did not find any evidence for a ring-like configuration of condensed chromatin or microtubule inclusions as reported by others after griseofulvin or nocodazole treatment (Gull \& Trinci, 1974; Wright et al., 1976; Herbert et al., 1980 ), but this was probably due to the fact that in these latter reports nuclei were examined after much longer exposure to the drugs. The observations reported here substantiate previous work which had indicated that only completion of the initial stages of mitosis are necessary to trigger DNA replication (Brewer \& Rusch, 1968; Wright \& Tollon, 1978; Wolf et al., 1979; Wright et al., 1984). Mitosis and preparation for DNA replication may therefore be triggered by the same mechanism. For example, the structural alterations accompanying chromosome condensation may be sufficient to trigger DNA synthesis. Limited DNA replication in the presence of nocodazole may be due to a lack of decondensation of chromosomes with a consequent reduction in replication.

If it is assumed that the action of nocodazole is restricted to the inhibition of microtubule assembly (Quinlan et al., 1981) it is difficult to explain why treatment of a plasmodium for $2 \mathrm{~h}$ or more prior to mitosis should prevent even the initiation of the process. Synthesis of tubulin proteins begins 2 to $3 \mathrm{~h}$ before metaphase, but microtubules are first observed only some $30 \mathrm{~min}$ before metaphase (Schedl et al., 1984). In the plasmodial phase of the organism, microtubules are present only during mitosis and cytoplasmic microtubules have not been observed (Burland et al., 1983). Treatment of cultured mammalian cells with nocodazole strongly depressed tubulin synthesis while having little effect on protein synthesis generally (Ben-Ze'er et al., 1979). This is due to a decline in translatable mRNA (Cleveland et al., 1981; Cleveland \& Havercroft, 1983) and an autoregulation model was proposed whereby increased levels of unpolymerized tubulin, caused by the action of nocodazole, depress further tubulin synthesis by reducing the levels of translatable mRNA. This autoregulation appears to be very sensitive as tubulin synthesis was suppressed after injection of tubulin which raised the total cellular content by only 25 to $50 \%$ (Cleveland et al., 1983). Thus nocodazole, if added sufficiently early in G2, may act to raise the tubulin promoter pool in $P$. polycephalum with a consequent effect on tubulin RNA synthesis which normally begins some $5 \mathrm{~h}$ before mitosis (Schedl et al., 1984). The rise in tubulin RNA synthesis may be a significant factor in priming the plasmodium for mitosis.

If nocodazole interfered with the control signals that ensured co-ordination of the mitotic cycle, it would also explain why the normal increase in TdR kinase was prevented by nocodazole treatment $2 \mathrm{~h}$ or more prior to mitosis. From temperature-shift experiments, Wright \& Tollon $(1978,1979 b)$ have suggested the existence of a heat-sensitive pathway which is necessary for 
triggering both the increase in $\mathrm{TdR}$ kinase activity and the onset of mitosis. Nocodazole may be interfering with the regulation of the same pathway of events.

The absence of any significant G1 phase in growing plasmodia has been well documented and, although it has not been studied in as much detail, the absence of a Gl phase during starvation has also been reported (Guttes \& Guttes, 1961; Mohberg \& Rusch, 1971). The fact that nocodazole had similar effects on growing and starving plasmodia, with regard to the point of addition prior to mitosis at which the drug still allowed limited DNA replication to occur, implied that no prolonged $\mathrm{Gl}$ period existed in the starved plasmodia. A lengthened Gl period would have meant that the drug would have had to be added for a period longer than $2 \mathrm{~h}$ prior to a round of DNA replication to completely block DNA synthesis. Chapman \& Coote (1982) found that plasmodia were sensitive to nocodazole inhibition of sporulation late in starvation, many hours after the last detectable round of DNA replication. If this nocodazole-sensitive event was an isolated mitosis, unaccompanied by DNA replication, it would mean that the plasmodia were in the Gl phase when they developed competence to sporulate at $72 \mathrm{~h}$. The data presented here do not support this idea, but rather suggest that nocodazole may be interfering with the role of microtubules in processes necessary for morphogenesis, but not concerned with mitosis.

A.S.M. was the recipient of an SERC Research Studentship. We thank M. Achison for skilled technical assistance and $\mathrm{A}$. Ellis for help with the electron microscopy.

\section{REFERENCES}

Ben-Ze'er, A., Farmer, S. R. \& Penman, S. (1979). Mechanisms of regulating tubulin synthesis in cultured mammalian cells. Cell 17, 319-325.

Braun, R., Mittenmayer, C. \& Rusch, H. P. (1965). Sequential temporal replication of DNA in $P h y$ sarum polycephalum. Proceedings of the National Academy of Sciences of the United States of America 53, 924-931.

Brewer, E. N. \& Rusch, H. P. (1968). Effect of elevated temperature shocks on mitosis and on the initiation of DNA replication in Physarum polycephalum. Experimental Cell Research 49, 79-86.

Burland, T. G., Gull, K., SChedl, T., Boston, R. S. \& Dove, W. F. (1983). Cell type-dependent expression of tubulins in Physarum. Journal of Cell Biology 97, 1852-1859.

Chapman, A. \& Coote, J. G. (1982). Sporulation competence in Physarum polycephalum $\mathrm{CL}$ and the requirement for DNA replication and mitosis. Journal of General Microbiology 128, 1489-1501.

Cleveland, D. W. \& Havercroft, J. C. (1983). Is apparent autoregulatory control of tubulin synthesis nontranscriptionally regulated? Journal of Cell Biology 97, 919-924.

Cleveland, D. W., lopata, M. A., Sherline, P. \& KIRSCHNER, M. W. (1981). Unpolymerised tubulin modulates the level of tubulin mRNAs. Cell 25 , 537-546.

Cleveland, D. W., Pittenger, M. F. \& Feramisco, J. R. (1983). Elevation of tubulin levels by microinjection suppresses new tubulin synthesis. Nature, London 305, 738-740.

COOKE, D. J. \& DEE, J. (1975). Methods for the isolation and analysis of plasmodial mutants in Physarum polycephalum. Genetical Research 24, 175187.
Gull, K. \& Trinci, A. P. J. (1974). Ultrastructural effects of griseofulvin in the myxomycete Physarum polycephalum. Protoplasma 81, 37-48.

GUTTES, E. \& GuTTES, S. (1961). Synchronous mitosis in starved plasmodia of the myxomycete Physarum polycephalum. Federation Proceedings 20, 419.

GUTTES, E. \& GUTTES, S. (1964). Mitotic synchrony in the plasmodia of Physarum polycephalum and mitotic synchronisation by coalescence of microplasmodia. Methods in Cell Physiology 1, 43-54.

Guttes, E., Guttes, S. \& RusCh, H. P. (1961). Morphological observations on growth and differentiation of Physarum polycephalum grown in pure culture. Developmental Biology 3, 588-614.

GuTTES, S. \& GuTTES, E. (1968). Regulation of DNA replication in the nuclei of the slime mould Physarum polycephalum. Transplantation of nuclei by plasmodial coalescence. Journal of Cell Biology 37, 761-772.

Herbert, C. D., Steffens, W. L. \& Wille, J. J. (1980). The role of spindle microtubule assembly in the control of mitotic timing in Physarum. Induction of a novel type of tubular structure by griseofulvin treatment. Experimental Cell Research 126, 1-13.

Kubbies, M. \& Pierron, G. (1983). Mitotic cell cycle control in Physarum. Unprecendented insight via flow-cytometry. Experimental Cell Research 149, 5767.

MOHBERG, J. \& RUSCH, H. P. (1971). Isolation and DNA content of nuclei of Physarum polycephalum. Experimental Cell Research 66, 305-316.

Quinlan, R. A., Roobol, A., Pogson, C. I. \& Gull, $\mathrm{K}$. (1981). A correlation between in vivo and in vitro effects of the microtubule inhibitors colchicine, parbendazole and nocodazole on myxamoebae of Physarum polycephalum. Journal of General Microbiology 122, 1-6. 
Sachsenmaier, W., Fournier, D. V. \& Gurtler, K. F. (1967). Periodic thymidine kinase production in synchronous plasmodia of Physarum polycephalum. Inhibition by actinomycin and actidion. Biochemical and Biophysical Research Communications 27, 655-660.

Sachsenmaier, W., Bohnert, E., Clausnizer, B. \& NYGAARD, O. F. (1970). Cycle dependent variation of X-ray effects on synchronous mitosis and thymidine kinase induction in Physarum polycephalum. FEBS Lettters 10, 185-189.

SAUER, H. W., BABCOCK, K. L. \& RusCh, H. P. (1969). Sporulation in Physarum polycephalum. A model system for studies on differentiation. Experimental Cell Research 57, 319-327.

Schedl, T., Burland, T: G., Gull, K. \& Dove, W. F. (1984). Cell cycle regulation of tubulin RNA level, tubulin protein synthesis and assembly of microtubules in Physarum. Journal of Cell Biology 99, 155165.

Wolf, R., Wick, R. \& Sauer, H. W. (1979). Mitosis in Physarum polycephalum: analysis of time-lapse films and DNA replication of normal and heat-shocked macroplasmodia. European Journal of Cell Biology 19, 49-59.
Wright, M. \& Tollon, Y. (1978). Heat sensitive factor necessary for mitosis onset in Physarum polycephalum. Molecular and General Genetics 163, 91-99.

Wright, M. \& Tollon, Y. (1979a). Physarum thymidine kinase: a step or a peak enzyme depending upon temperature of growth. European Journal of Biochemistry 96, 177-181.

Wright, M. \& Tollon, Y. (1979b). Regulation of thymidine kinase synthesis during the cell cycle of Physarum polycephalum by the heat-sensitive system which triggers mitosis and $\mathrm{S}$ phase. Experimental Cell Research 122, 273-279.

Wright, M., Moisand, A., Tollon, Y. \& Oustrin, M.-L. (1976). Mise en évidence de l'action du methyl benzimidazole-2-ylcarbamate (BMC) et du methyl [5(2-thienyl-carbonyl)-1-H benzimidazole-2-yl carbamate] (R17934) sur le noyau de Physarum polycephalum. Comptes rendus de l'Acádemie des sciences 283D, 1361-1364.

Wright, M., Lacorre-Arescaldino, I., Macquet, J. P. \& DAFFE, M. (1984). Induction of polyploid nuclei in the plasmodium of Physarum polycephalum by platinum anti-tumour compounds. Cancer $R e$ search 44, 777-783. 